\title{
Interaction between Phytoplankton and Epiphytic Algae in the Kaniv Water Reservoir (Ukraine)
}

\section{Hanna Zadorozhna ${ }^{a}{ }^{*}$, Nataliia Semeniuk ${ }^{b}$ and Volodymyr Shcherbak ${ }^{c}$}

\author{
Institute of Hydrobiology of the National Academy of Sciences of Ukraine, \\ 12 Geroiv Stalingrada Avenue, Kyiv, 04210, Ukraine \\ aanna_zadorozhna@ukr.net, ${ }^{b}$ natasemenyuk@gmail.com, ${ }^{c}$ ek424nat@ukr.net
}

\begin{abstract}
Keywords: phytoplankton, epiphytic algae, Kaniv Water Reservoir, species similarity, biomass, Shannon's diversity index, temperature.
\end{abstract}

\begin{abstract}
The paper considers the patterns of interaction between algae relating to different ecological groups (phytoplankton and epiphytic algae) in the upper section of the Kaniv Water Reservoir (Ukraine). Phytoplankton and epiphytic algae have been shown to form the dynamic system, wherein phytoplankton makes an impact upon the epiphytic algal community structure, and, on the contrary, epiphytic algae in certain periods of the year can influence the phytoplankton structure. Several species were simultaneously present in both communities, and this was caused by: their habitat versatility, algae sedimentation from plankton to higher aquatic plant surface and transition of typically epiphytic species to plankton owing to hydrodynamic processes. The "phase opposition" was observed between phytoplankton and epiphytic algae: the maximal biomass of phytoplankton was recorded in summer, while that of epiphytic algae - in autumn. Such "phase opposition" is explained by different temperature optimums of dominant species and divisions in these communities, and also by shading of epiphytic algae by phytoplankton in case of intensive growth of the latter.
\end{abstract}

\section{Introduction}

Algae of different ecological groups are the principal components of autotrophic link in lowland water reservoirs' ecosystems. It is known that in eutrophic water-bodies, such as the Kaniv Water Reservoir, the major portion of organic matter is produced by phytoplankton. At the same time, a significant part (38\%) of the Kaniv Water Reservoir area is shallow (with the depths not exceeding $2.5 \mathrm{~m}$ ), providing favorable conditions for algal communities of different substrata, such as epiphyton.

Interaction among algae, relating to different ecological groups, under various abiotic conditions is one of urgent hydrobiological issues. Information search shows that studies devoted to mutual influence between phytoplankton and algal communities associated with substrata (such as benthos, periphyton) have been mainly conducted on lakes [1-5]. It is common knowledge that development of different algal communities depends upon solar radiation intensity. Competition for this resource may occur between phytoplankton and periphyton, where planktonic algae have a competitive advantage, because they are floating in the water column and can "intercept" solar radiation before it reaches periphyton. Due to this fact the so called "phase opposition" is often observed between phytoplankton and periphyton biomasses [5-7]. It should be pointed out that competition for solar radiation between phytoplankton and algal periphyton still remains an issue insufficiently explored.

The field study on interrelation between phytoplankton and periphytic algal communities along a productivity gradient of lakes ranging from extremely low productive to highly productive ones [1] showed a curvilinear relationship between the biomass of periphytic algae and lake productivity. It suggests that in oligotrophic lakes periphytic algae growth is limited by nutrients, and in eutrophic lakes - by available solar radiation, because high phytoplankton biomass can reduce light penetration [1]. It is believed [3, 4] that two regimes can be distinguished for lakes: 
high turbidity regime (due to high phytoplankton growth) and transparent water regime (when algae associated with different substrata develop intensively). High turbidity regime is shown to be a more steady state, and the particular lake's transition from one state to another depends both upon nutrient content and upon optical parameters of water.

The objective of the study was to reveal the patterns of interaction between algae relating to different ecological groups in the upper section of the Kaniv Water Reservoir.

\section{Materials and Methods}

The Kaniv Water Reservoir is the youngest reservoir in the Dnieper's cascade, filling of which was started in 1972 and completed in 1976. According to its principal morphometric parameters the reservoir relates to large lowland reservoirs with small depths. Its water-surface area makes up $564 \mathrm{~km}^{2}$, the volume $-2.62 \mathrm{~km}^{3}$, the length $-157 \mathrm{~km}$, the maximal depth $-21.0 \mathrm{~m}$, the average depth $-3.9 \mathrm{~m}$. The reservoir's water area can be divided into three sections according to hydromorphometric parameters: the upper one (river section) $63 \mathrm{~km}$ long, the middle one (transition section) $30 \mathrm{~km}$ long and the lower one (lake section) $30 \mathrm{~km}$ long [8].

The Kaniv Water Reservoir is located in the north of Ukraine on the border between the mixed forest zone and the forest-steppe zone. The climate in the region is temperate continental [9].

The field research was carried out in the upper section of the Kaniv Water Reservoir at the fixed monitoring site of the Institute of Hydrobiology of the National Academy of Sciences of Ukraine (N 50²9'57", E 30³1'31") from May till November during 2010-2011 (Fig. 1).

By "phytoplankton" we mean an aggregate of all microscopic algae, notwithstanding their typical habitat, which are in the water column at the moment of sampling. By "epiphytic algae" we mean microscopic algae associated with submerged parts of higher aquatic plants, with account taken of all species found in the suspension washed from the submerged surface of a higher plant.

Phytoplankton was sampled with Ruthner bathometer into labeled $1.0 \mathrm{dm}^{3}$ bottles. Samples were preserved with $40 \%$ formalin solution in the ratio of $1: 100$, concentrated by sedimentation method and processed within a month [10].

Epiphytic algae samples were collected from lakeshore bulrush (Schoenoplectus lacustris (L.) Palla), which is a dominant species of higher aquatic plants at the observation site. Plant fragments were cut under water, placed into labeled $100 \mathrm{~cm}^{3}$ jars and covered with distilled water. Back in the laboratory each jar was emptied into a tray, epiphytic algae were removed from plant fragments with a special brush, and the obtained suspension was funneled back into the same jar. After that the plant fragments were dried in the drying cabinet at $105^{\circ} \mathrm{C}$ to absolute dry mass and weighted on the analytical scales within the accuracy of $0.01 \mathrm{mg}[10]$.

Algal samples were analyzed under microscopes MBB-1A, Amplival and Axio Imager (Carl Zeiss) with the ocular lenses $K 7 \times, 15 \times$ and the objectives $\times 20, \times 40 \mathrm{i} \times 100$. Taxonomical names are given in accordance with [11]. Diatoms were identified more precisely by diatom analysis $[12,13]$.

Phytoplankton number of cells was calculated per $1 \mathrm{dm}^{3}$ with the help of $0.02 \mathrm{~cm}^{3}$ Nageotte chamber according to the following formula (Eq. 1):

$$
N=k n\left(\frac{A}{a}\right) v\left(\frac{1000}{V}\right),
$$

where $N$ - number of algal cells in $1 \mathrm{dm}^{3}$ of the sample under study [cells $\cdot \mathrm{dm}^{-3}$ ]; $k$ - coefficient showing how many times the volume of the used counting chamber is less than $1 \mathrm{~cm}^{3} ; n$ - number of algal cells in the chamber strips counted; $A$ - number of strips in the counting chamber; $a$ - number of strips counted; $v$ - concentrated sample volume $\left[\mathrm{cm}^{3}\right] ; V$ - initial volume of the sample collected; 1000 - coefficient of converting cubic centimeters into cubic decimeters. 
Epiphytic algae number was calculated per $1 \mathrm{~g}$ of absolute dry mass (ADM) of a higher aquatic plant in accordance with the following equation (Eq. 2):

$$
N=k n\left(\frac{A}{a}\right) \cdot\left(\frac{v}{p}\right),
$$

where $N$ - number of algal cells per $1 \mathrm{~g}$ of ADM of a plant [cells.g $\left.{ }^{-1} \mathrm{ADM}\right] ; k$ - coefficient showing what fold the volume of the used counting chamber is less than $1 \mathrm{~cm}^{3} ; n$-number of algal cells in the chamber strips counted; $A$ - number of strips in the counting chamber; $a$ - number of strips counted; $v$ - sample volume $\left[\mathrm{cm}^{3}\right] ; p-$ absolute dry mass of the plant fragment, which epiphytic algae were removed from $[\mathrm{g}]$.

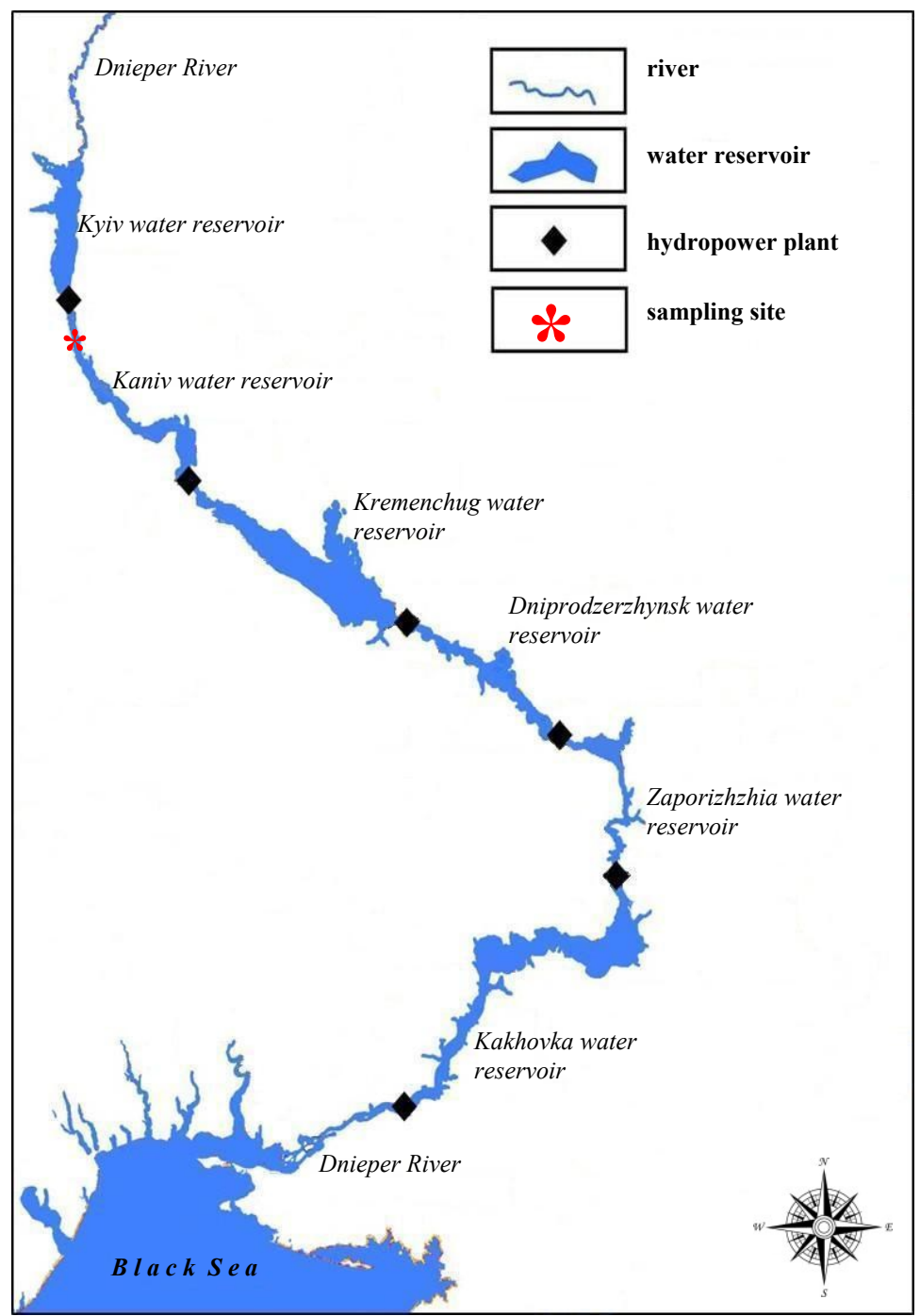

Figure 1. Schematic map of water reservoirs cascade on the Dnieper River and location of the sampling site.

Biomass of phytoplankton and epiphytic algae was determined by standard volumetric method [10]. This method consists in matching the algal cells' shapes with geometrical bodies (sphere, ellipsoid, cylinder, cone etc.), measuring their linear dimensions and calculating their volumes in accordance with generally known equations. In order to calculate the cell volume of some diatoms possessing compound shapes we applied coefficients of volumetric fullness $[14,15]$. We assume that the relative density of an algal cell is equal to 1 . The calculated volume of each species was multiplied by its number of cells and its biomass was obtained, represented in $\left[\mathrm{mg} \cdot \mathrm{dm}^{-3}\right]$ for phytoplankton and $\left[\mathrm{mg} \cdot \mathrm{g}^{-1} \mathrm{ADM}\right]$ for epiphytic algae. 
To characterize phytoplankton and epiphytic algal community we distinguished dominant species, whose number of cells or biomass was equal to or exceeded $10 \%$ of the total number of cells (biomass), and subdominant species with number of cells (biomass) making up 5.0-9.9\% of the total number of cells (biomass) in the community.

The average cenotic volume of algal communities $[16,17]$ was calculated in accordance with the following equation (Eq. 3).

$$
A C V=\frac{B}{N},
$$

where $A C V$ - average cenotic volume of phytoplankton or epiphytic algal community [ $\left.\mathrm{mcm}^{3}\right]$; $B$ - biomass of phytoplankton or epiphytic algal community; $N$ - number of cells of phytoplankton or epiphytic algal community.

Species similarity of planktonic and epiphytic algal communities was estimated with the help of Sorensen similarity index [18] according to the following equation (Eq. 4):

$$
K_{S}=\frac{2 c}{a+b},
$$

where $K_{S}$ - Sorensen similarity index between community $a$ and community $b$; c - number of common species; $a$-number of species in community $a ; b$ - number of species in community $b$.

Shannon's diversity index [19] was calculated in accordance with the following equation (Eq. 5):

$$
H_{N}=-\sum_{i=1}^{s} \frac{n_{i}}{n} \log _{2} \frac{n_{i}}{n}
$$

where $H_{N}$ - Shannon's index (on the basis of number of cells) [bits.ind $\left.{ }^{-1}\right] ; n_{i}-$ number of individuals (cells), belonging to the $i$ th species in the algal community; $n$ - total number of individuals (cells) in the algal community; $s$ - number of species in the algal community.

During each sampling we recorded water temperature, dissolved oxygen content and its saturation, inorganic nitrogen and phosphorus content in water [10, 20].

The data on total solar radiation for the upper section of the Kaniv Water Reservoir were obtained from the archives of the Central Geophysical Observatory of Ukraine [21].

Statistical processing of the data massif was done with Statistica, Past, and MS Excel software.

The study area according to the main abiotic parameters is characterized in the Table 1 .

The temperature dynamics was marked by maximal values in summer season. In the early August 2010 we recorded its abnormally high value $\left(28.1^{\circ} \mathrm{C}\right)$. At the same time, the water temperature maximum noticed in the late July 2011 made up $25.4^{\circ} \mathrm{C}$.

The dissolved oxygen content was distinguished by significant variability. Maximums of this parameter were recorded both in summer (due to intensive phytoplankton photosynthesis) and in late autumn owing to atmospheric aeration of water. In the late September 2010 we observed oxygen deficit ( $41 \%$ of saturation), which in our opinion was related to blue-green algae biomass decomposition after water blooming.

The Kaniv Water Reservoir refers to eutrophic water bodies. During the vegetation period the dissolved inorganic phosphorus content fluctuated from analytical zero in spring to $0.13 \mathrm{mg} \mathrm{P} \cdot \mathrm{dm}^{-3}$ in summer, the total inorganic nitrogen content - from $0.26 \mathrm{mg} \mathrm{N} \cdot \mathrm{dm}^{-3}$ in autumn to $1.33 \mathrm{mg} \mathrm{N} \cdot \mathrm{dm}^{-3}$ in spring [22]. 
Table 1. Main abiotic parameters of the uppers section of the Kaniv Water Reservoir ${ }^{1,2}$.

\begin{tabular}{|l|c|}
\hline \multicolumn{1}{|c|}{ Parameters } & Values \\
\hline Water temperature $\left[{ }^{\circ} \mathrm{C}\right]$ & $\frac{3.2-28.1}{17.9 \pm 1.3}$ \\
\hline Total solar radiation $\left[\mathrm{J} \cdot \mathrm{m}^{-2}\right]$ & $\underline{10-830}$ \\
\hline Dissolved oxygen $\left(\mathrm{O}_{2}\right)\left[\mathrm{mg} \cdot \mathrm{dm}^{-3}\right]$ & $\frac{4.00-13.91}{7.90 \pm 0.37}$ \\
\hline Oxygen saturation $[\%]$ & $\underline{41-132}$ \\
\hline Dissolved inorganic phosphorus $\left[\mathrm{mg} \mathrm{P} \cdot \mathrm{dm}^{-3}\right][22]$ & $\frac{0-0.13}{82 \pm 3}$ \\
\hline Dissolved inorganic nitrogen $\left[\mathrm{mg} \mathrm{P} \cdot \mathrm{dm}^{-3}\right][22]$ & $0.06 \pm 0.008$ \\
\hline Permanganate oxidation $\left[\mathrm{mg} \mathrm{O} \cdot \mathrm{dm}^{-3}\right]$ & $\underline{0.26-1.33}$ \\
\hline Dichromate oxidation $\left[\mathrm{mg} \mathrm{O} \cdot \mathrm{dm}^{-3}\right]$ & $0.48 \pm 0.04$ \\
\hline Current velocity $\left[\mathrm{m} \cdot \mathrm{s}^{-1}\right][23]$ & $\frac{9.2-21.5}{15.8 \pm 0.5}$ \\
\hline Bottom [23] & $\underline{13.7-42.7}$ \\
\hline Degree of overgrowing with higher aquatic plants $[\%][23]$ & $28.8 \pm 1.1$ \\
\hline
\end{tabular}

Note. Above the bar - fluctuation margins, below the bar - average values \pm standard error.

${ }^{1}$ The data on water temperature, total solar radiation, dissolved oxygen content, oxygen saturation of water, inorganic nitrogen and phosphorus content are given according to our field observations carried out in May-November 2010-2011.

${ }^{2}$ The data on permanganate and dichromate oxidation for the studied period are a courtesy of junior researcher of the Institute of Hydrobiology of the NAS of Ukraine Mariia Ivanivna Linchuk.

\section{Results and Discussion}

General description of phytoplankton. 209 species including infraspecific taxa relating to 8 divisions (Cyanophyta (= Cyanoprokaryota, Cyanobacteria), Euglenophyta, Dinophyta, Cryptophyta, Chrysophyta, Bacillariophyta, Xanthophyta, Chlorophyta) were identified in phytoplankton of the upper section of the Kaniv Water Reservoir for the period under study. The taxonomic structure was dominated by green algae $(38 \%$ of the total number of species and varieties), diatoms $(32 \%)$ and to a less extent blue-green algae (14\%). The algae relating to other divisions were represented by small number of species, whose share varied within $2-5 \%$.

Phytoplankton dynamics showed high species richness in summer (up to $45-53$ species in a sample) and significant decline in the number of species in autumn (to 8-10 species in a sample). It is necessary to note that the summer phytoplankton was distinguished by a large share of green algae (48\% of the number of species), while the autumn phytoplankton - by a large one of Bacillariophyta (42\%).

Phytoplankton number of cells and biomass varied widely (196-244416 thousand cells $\cdot \mathrm{dm}^{-3}$ with the average of $13568 \pm 6749$ thousand cells $\cdot \mathrm{dm}^{-3}$ and $0.062-21.190 \mathrm{mg} \cdot \mathrm{dm}^{-3}$ with the average 
of $2.200 \pm 0.592 \mathrm{mg} \cdot \mathrm{dm}^{-3}$ respectively), reaching maximal value in summer. The summer phytoplankton was dominated by Cyanophyta ( $83 \%$ of the cell number and $44 \%$ of the biomass), while in the autumn phytoplankton Bacillariophyta prevailed $(45 \%$ of the cell number and $82 \%$ of the biomass). The data on phytoplankton number of cells and biomass broken down by taxonomic divisions are given in Table 2.

Table 2. Number of cells $(N)$ and biomass $(B)$ of planktonic and epiphytic algae in the upper section of the Kaniv Water Reservoir (May-November).

\begin{tabular}{|c|c|c|c|c|}
\hline \multirow[b]{2}{*}{ Divisions } & \multicolumn{2}{|c|}{ Phytoplankton } & \multicolumn{2}{|c|}{ Epiphytic algal communities } \\
\hline & $\begin{array}{l}N, \text { thousand } \\
\text { cells } \cdot \mathrm{dm}^{-3}\end{array}$ & $B, \mathrm{mg} \cdot \mathrm{dm}^{-3}$ & $\begin{array}{c}N, \text { thousand } \\
\text { cells } \cdot g^{-1} \mathrm{ADM}\end{array}$ & $B, \mathrm{mg} \cdot \mathrm{g}^{-1} \mathrm{ADM}$ \\
\hline Cyanophyta & $\frac{0-236976}{10173 \pm 6597}$ & $\frac{0-17.428}{0.623 \pm 0.487}$ & $\frac{0-55439}{5279 \pm 2964}$ & $\frac{0-1.160}{0.091 \pm 0.058}$ \\
\hline Euglenophyta & $\frac{0-80}{11 \pm 2}$ & $\frac{0-0.221}{0.032 \pm 0.008}$ & $\frac{0-28}{1 \pm 1}$ & $\frac{0-0.060}{0.003 \pm 0.003}$ \\
\hline Dinophyta & $\frac{0-112}{13 \pm 3}$ & $\frac{0-0.820}{0.092 \pm 0.030}$ & $\frac{0-76}{5 \pm 4}$ & $0 . \frac{0-1.578}{0.081 \pm 0.077}$ \\
\hline Cryptophyta & $\frac{0-240}{22 \pm 8}$ & $\frac{0-0.122}{0.0133 \pm 0.004}$ & $\frac{0-20}{1 \pm 1}$ & $\frac{0-0.045}{0.002 \pm 0.002}$ \\
\hline Chrysophyta & $\frac{0-90}{12 \pm 3}$ & $\frac{0-0.036}{0.005 \pm 0.001}$ & $\frac{0-152}{8 \pm 7}$ & $\frac{0-0.104}{0.006 \pm 0.005}$ \\
\hline Bacillariophyta & $\frac{58-7672}{2042 \pm 332}$ & $\frac{0.057-3.933}{1.085 \pm 0.176}$ & $\frac{234-10298}{4067 \pm 752}$ & $\frac{0.117-18.320}{5.360 \pm 1.146}$ \\
\hline Xanthophyta & $\frac{0-96}{10 \pm 3}$ & $\frac{0-0.049}{0.005 \pm 0.002}$ & - & - \\
\hline Chlorophyta & $\frac{0-8432}{1284 \pm 287}$ & $\frac{0-1.653}{0.347 \pm 0.065}$ & $\frac{0-1340}{213 \pm 73}$ & $\frac{0-1.964}{0.259 \pm 0.102}$ \\
\hline
\end{tabular}

Note. Above the bar - fluctuation margins, below the bar - average values \pm standard error.

The dominant species complex (according to biomass) in early summer was marked by significant abundance of a centric diatom Aulacoseira granulata (Ehrenberg) Simonsen, which was later on succeeded by Anabaena flos-aquae Brébisson ex Bornet \& Flauhault and Microcystis aeruginosa (Kützing) Kützing, causing water blooms in the reservoir section studied. At the beginning of autumn it was again Aulacoseira granulata that prevailed in phytoplankton, and in October-November it was replaced by Skeletonema potamos (C.I. Weber) Hasle, Stephanodiscus hantzschii Grunow and Cyclotella kuetzingiana Chauvin.

General description of epiphytic algal communities. 140 species and infraspecific taxa relating to 7 divisions (Cyanophyta, Euglenophyta, Dinophyta, Cryptophyta, Chrysophyta, Bacillariophyta, Chlorophyta) were identified in epiphytic algal communities for the observation period. The taxonomic composition was formed by diatoms $(58 \%$ of the total number of species and varieties), green algae (24\%) and blue-green algae (12\%). The share of other divisions was insignificant and did not exceed $1-2 \%$.

The epiphytic algae number of cells varied from 950 to 55738 thousand cells.g ${ }^{-1}$ ADM (with the average of $9576 \pm 3082$ thousand cells $\cdot \mathrm{g}^{-1} \mathrm{ADM}$ ), and the biomass - from 0.361 to $19.020 \mathrm{mg} \cdot \mathrm{g}^{-1}$ ADM (with the average of $5.802 \pm 1.243 \mathrm{mg} \cdot \mathrm{g}^{-1} \mathrm{ADM}$ ). In summer the algal number of cells was dominated by diatoms and blue-green algae, and the biomass - by diatoms and green algae. In 
autum diatoms prevailed both in number and in biomass. The dominant species complex during the period of observations was formed by Melosira varians C. Agardh, Cocconeis placentula Ehrenberg, Navicula tripunctata (O.F. Müller) Bory, Cymbella tumida (Brébisson) Van Heurck, Cymbella helvetica Kützing, Lyngbya kuetzingii Schmidle, Cosmarium formosulum Hoff.

One should note that unlike phytoplankton, whose qualitative and quantitative parameters declined from summer to autumn, in epiphytic algal communities the number of species, the number of cells and the biomass, on the contrary, increased. It is explained by the fact that epiphytic algal communities are dominated by diatoms whose highest growth in observed in autumn.

Phytoplankton's effect upon epiphytic algal communities. It is known $[24,25]$ that epiphytic algae growth is to a large extent limited by the availability of space for colonization. On the one hand, competition for the available space may support the species structure stability at each stage of the seasonal dynamics (the so called "interactive mechanism"). On the other hand, the river hydrological conditions contribute to intensive migration between planktonic and epiphytic communities. The algae sedimentating from the water column colonize the free space areas appearing on the substratum, and, owing to this, the community can maintain a relatively stable number of species (so called "non-interactive mechanism"). Therefore it is believed that the similarity between the species composition of epiphytic algal community and that of phytoplankton may reflect different patterns of species exchange in the "phytoplankton $\leftrightarrow$ epiphytic algal community" system. By measuring such similarity at each stage of the seasonal dynamics one can evaluate the role of the non-interactive mechanism (algae sedimentation from plankton) in forming the epiphyton structure $[24,25]$.

In the view of the above we analyzed the seasonal dynamics of planktonic and epiphytic algal communities' species richness, as well as the species similarity index between them, taking the year of 2010 as an example.

During the vegetation period phytoplankton species richness varied from 10 to 53 species and varieties - and that of epiphytic algae - from 12 to 35 species and varieties respectively (Fig. 2).

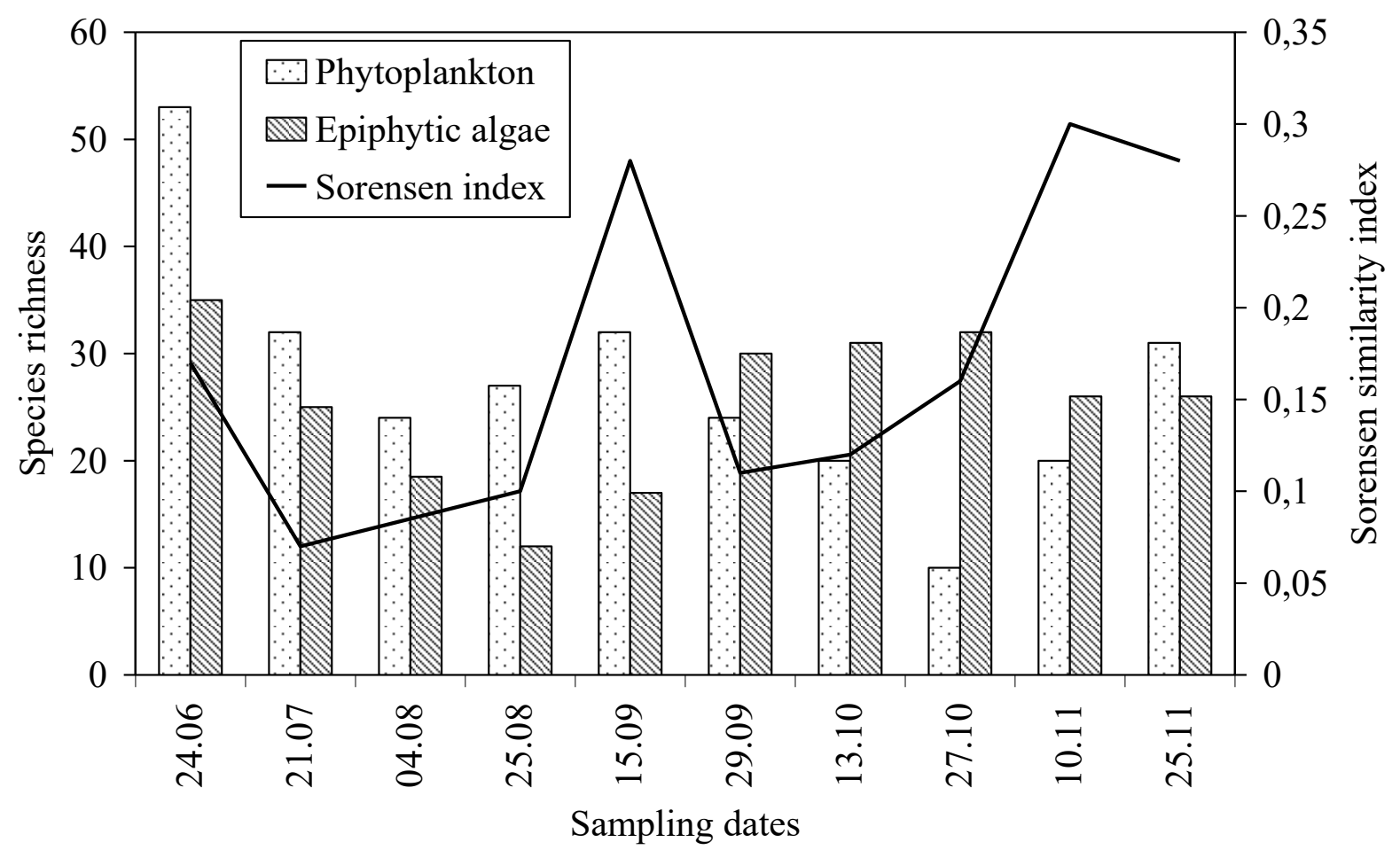

Figure 2. Seasonal dynamics of species richness in the "phytoplankton $\leftrightarrow$ epiphytic algal community" system and Sorensen similarity index between phytoplankton and epiphytic algal community in the upper section of the Kaniv Water Reservoir. 
The highest species richness both of phytoplankton and epiphytic algal community was recorded in the late June, with Sorensen similarity index equal to 0.17. In July Sorensen index decreased to 0.07, while in August-September it reached 0.12-0.28. Such an increase in species similarity in the "phytoplankton $\leftrightarrow$ epiphytic algal community" system may be related to water bloom caused by blue-green algae (Microcystis aeruginosa, Anabaena flos-aquae), with the phytoplankton biomass reaching $21.19 \mathrm{mg} \cdot \mathrm{dm}^{-3}$. Due to surge, these species partially settled down upon the surface of higher aquatic plants, and consequently were recorded in epiphyton samples. Further on the intensive water bloom began to "screen" the water column from solar radiation, which caused a decline in the species richness and biomass of epiphytic algae, especially of typical diatom species associated with higher aquatic plants. After the water bloom subsided and blue-green algae died off, a certain share of free space became available on the plant substratum, upon which planktonic species began settling down. Such assumption is confirmed by the fact that such typical planktonic species as Aulacoseira granulata, Desmodesmus communis (E. Hegewald) E. Hegewald were recorded in the epiphytic algal community at that time, and also by the fact that the species richness of phytoplankton was higher than that of epiphytic algae (see Fig. 2).

In October, when the water temperature dropped down significantly, the phytoplankton species richness and biomass reduced. This caused an increase in the water transparency, consequently giving rise to the species richness of epiphytic algae, which became higher than the species richness of phytoplankton (see Fig. 2). At that time the species similarity between the algal communities was low. In the late October Sorensen index increased and in November reached the maximal value. In this case the rise in the species similarity in the "phytoplankton $\leftrightarrow$ epiphytic algal community" system can be explained by decomposition of higher aquatic plants and intensive water turnover, which is also confirmed by the fact that in this period certain diatoms typically associated with substrata (such as Cocconeis placentula, Planothidium lanceolatum (Brébisson ex Kützing) Lange-Bertalot, Rhoicosphenia abbreviata (C. Agardh) Lange-Bertalot) occurred in phytoplankton.

It turned out that between 2 and 7 species could be simultaneously present in both communities, and there were 16 such species in total. In our opinion, presence of species, common for the "phytoplankton $\leftrightarrow$ epiphytic algal community" system, can be explained:

1) by habitat versatility of species, that is, by their ability to live in different habitats. For example, Melosira varians relates to typically planktonic species, but it also can live in benthos and in periphyton, where it forms long band-shaped colonies;

2) by sedimentation of algae from plankton to the higher aquatic plants' surface. For example, Anabaena flos-aquae, Microcystis aeruginosa, Aulacoseira granulata are dominant planktonic species, and their presence in the epiphytic community is probably caused by sedimentation.

3) by transition of typically epiphytic species (Cocconeis placentula, Rhoicosphenia abbreviata, Planothidium lanceolatum, Gomphoneis olivaceum (Hustedt) Aysel) to plankton due to intensive water turnover and turbulence.

We have found a significant inverse correlation between Shannon's index (calculated on the basis of number of cells) of phytoplankton and epiphytic algal community $(r=-0.46, p<0.027$, $n=23$ ), which is an indication of a certain "phase opposition" between phytoplankton and epiphytic algal communities growth (Fig. 3).

The "antiphased" growth in the "phytoplankton $\leftrightarrow$ epiphytic algal community" system is confirmed by the seasonal dynamics of these communities' biomasses (Fig. 4). The figure shows that the maximal values of phytoplankton biomass and epiphytic algae biomass were observed in different seasons: phytoplankton - in summer, epiphytic algae - in autumn. Such non-coincidence between the maximums of the algal communities' growth can be considered one of the mechanisms satisfying the energetic demands of the aquatic ecosystem by the autotrophic link in different seasons. 


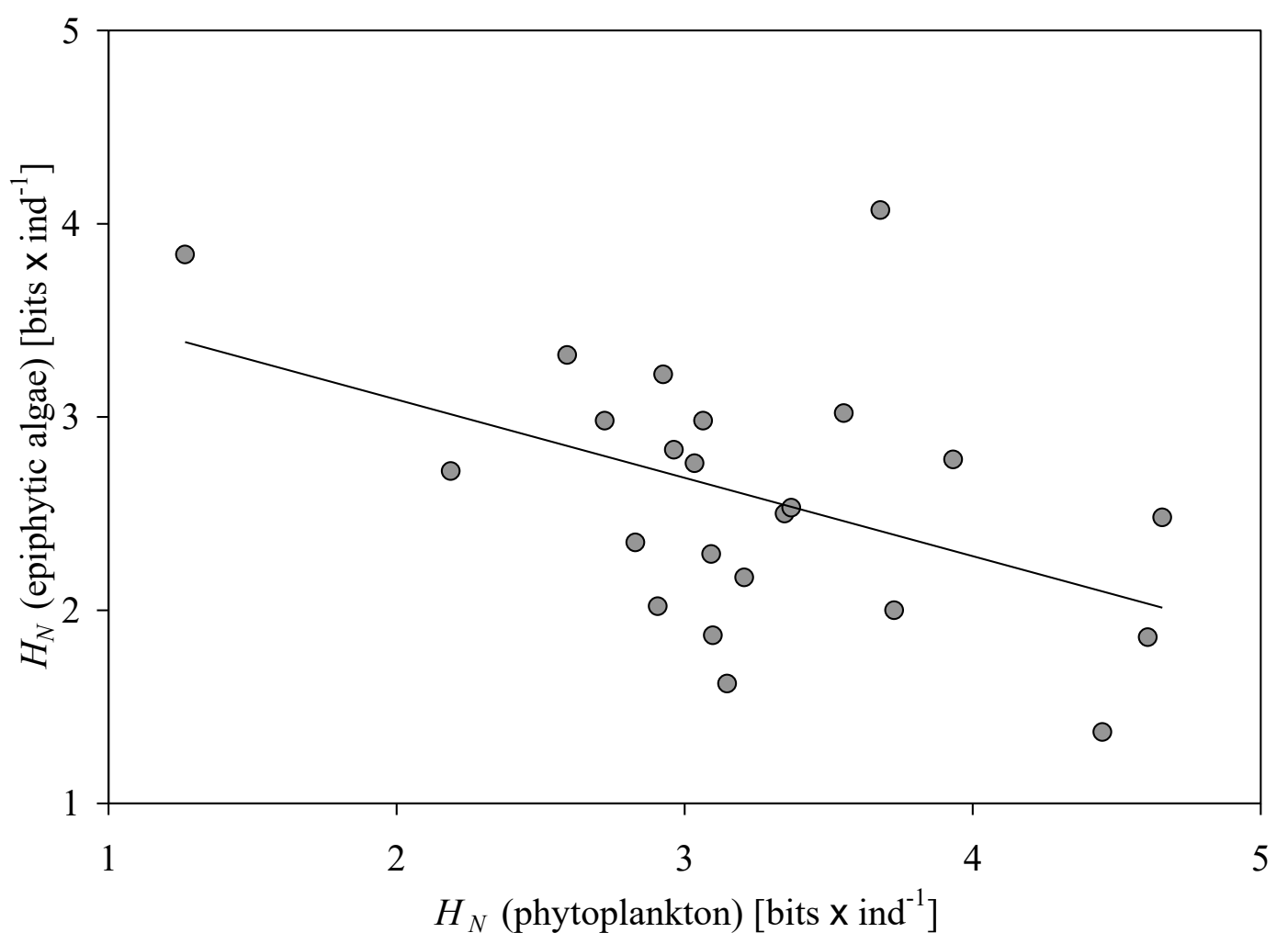

Figure 3. Correlation between Shannon's index of phytoplankton and epiphytic algal community.

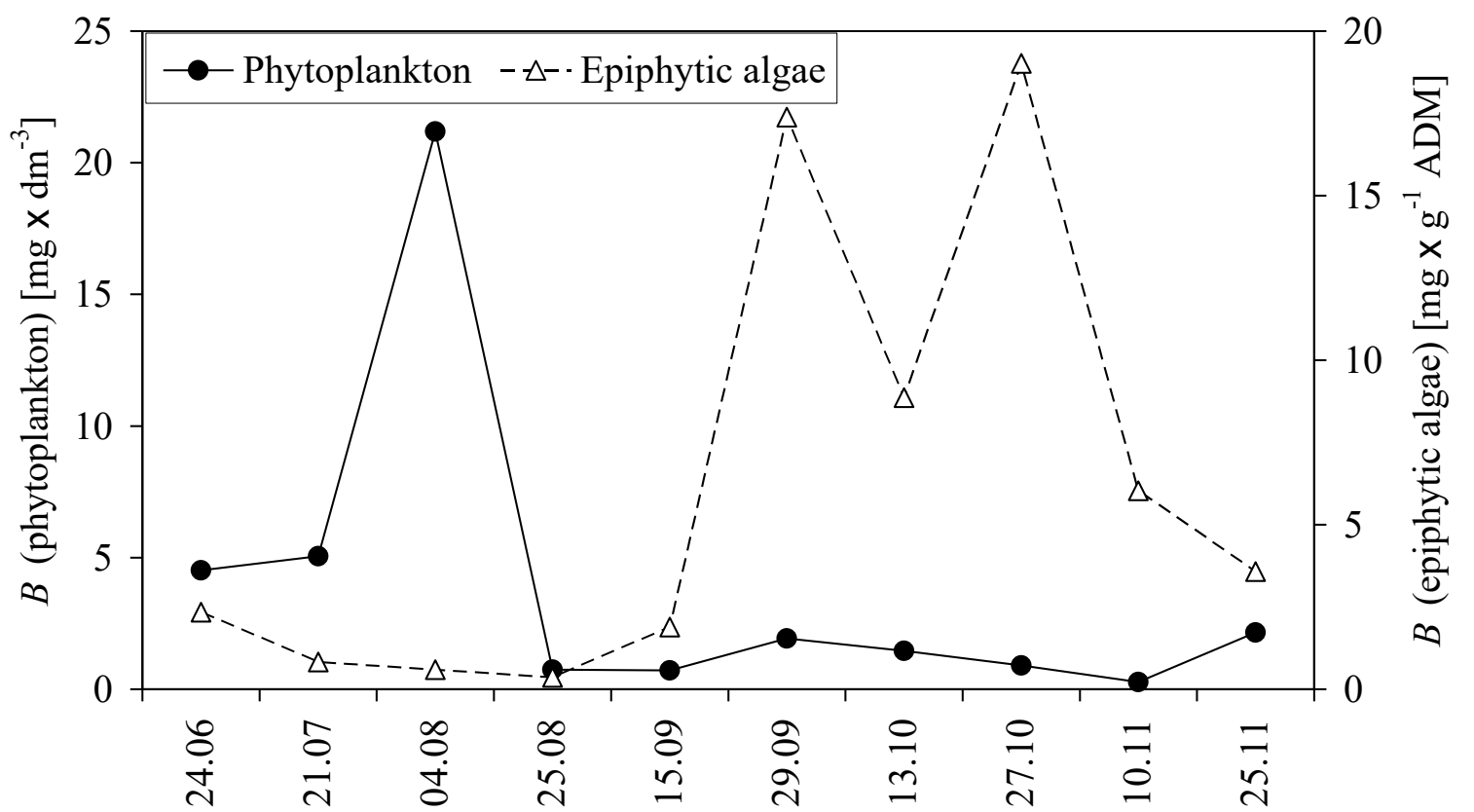

Sampling dates

Figure 4. Seasonal dynamics of biomass of phytoplankton and epiphytic algae in the upper section of the Kaniv Water Reservoir.

Thus, there is a clearly-marked interaction in the "phytoplankton $\leftrightarrow$ epiphytic algal community" system, wherein phytoplankton makes an impact upon the epiphytic algal community structure, and, on the contrary, epiphytic algae in certain periods of the year can influence the phytoplankton structure.

One of key abiotic factors, determining the algal communities' seasonal dynamics and structure in the Kaniv Water Reservoir, is water temperature [26]. It is explained by the fact that various species, divisions of algae have different temperature optimums of their growth. Since the 
taxonomic composition of phytoplankton is much different from that of epiphytic algal community, it is interesting to analyze the effect of water temperature upon functioning of the "phytoplankton $\leftrightarrow$ epiphytic algal community" system.

Correlation analysis showed a significant direct relation between water temperature (within a range of $\left.3.2-28.1^{\circ} \mathrm{C}\right)$ and the phytoplankton parameters: number of species $(r=0.70, p<0.0001$, $n=36)$, number of cells $(r=0.39, p=0.02, n=36)$, biomass $(r=0.48, p=0.003, n=36)$, Shannon's index $(r=0.43, p=0.008, n=36)$. At the same time, the epiphytic algal community demonstrated no correlation of these parameters with water temperature. It may be explained by the fact that the epiphytic algal community is mainly composed of diatoms, whose growth optimum falls within moderate temperature range $\left(10.0-20.0^{\circ} \mathrm{C}\right)$ [27], therefore the relation between water temperature and epiphyton is curvilinear, rather than linear.

Besides, the epiphytic algae biomass is to a great extent affected by phytoplankton, which, when attaining high biomass, can shade the water column from solar radiation, consequently inhibiting the epiphytic algae growth. As a result, the dynamics of phytoplankton and that of epiphytic algae are characterized by "phase opposition" [6, 7]. As an illustration, Fig. 5 demonstrates the distribution of phytoplankton and epiphytic algae biomasses along the water temperature gradient. When temperature increases, phytoplankton biomass definitely goes up, attaining its maximum at $28.0^{\circ} \mathrm{C}$, while epiphytic algae biomass shows more curvilinear distribution.

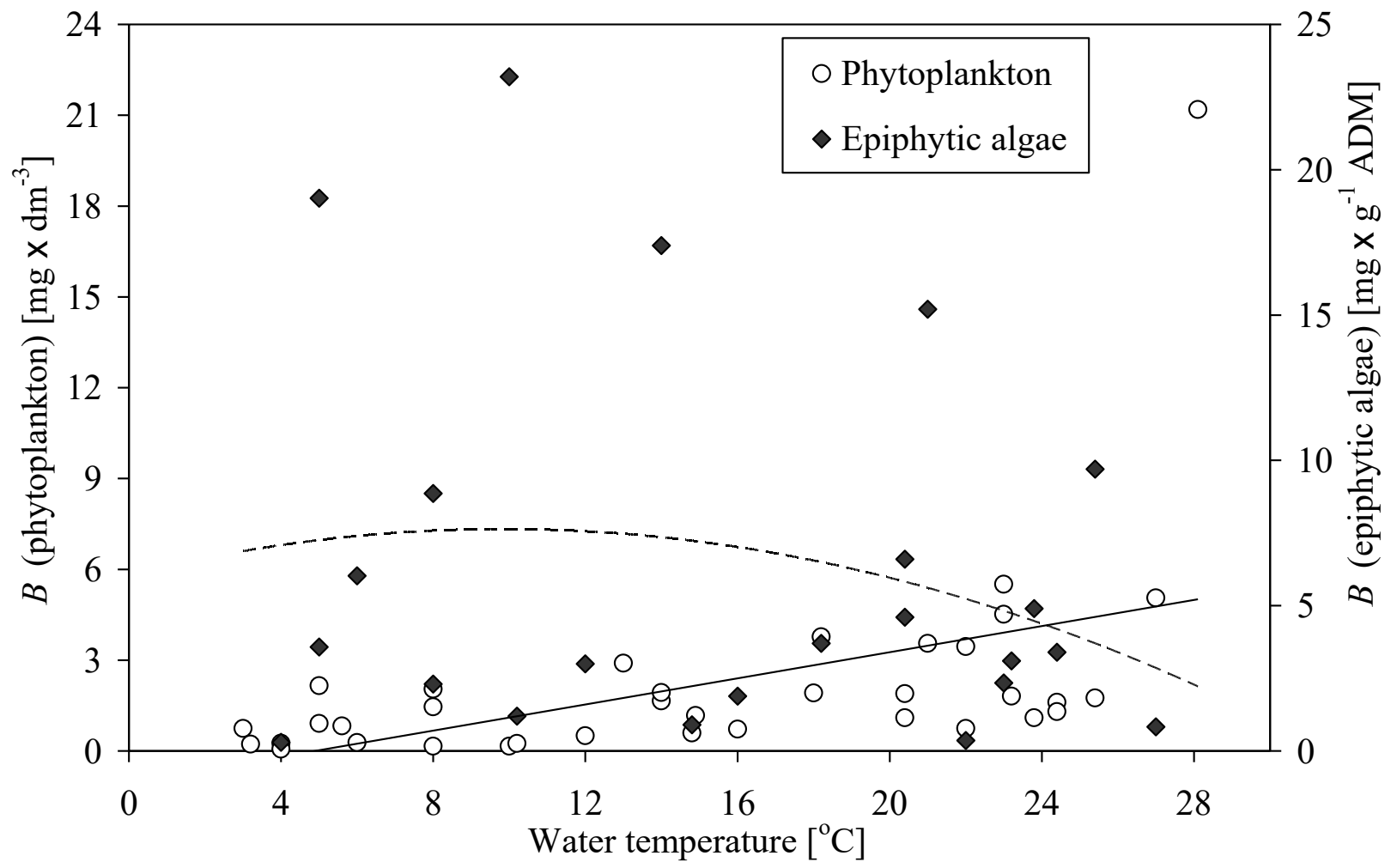

Figure 5. Distribution of phytoplankton and epiphytic algae biomass in relation to water temperature.

An important characteristic of algal communities is their dimensional structure, in particular, the average cenotic volume of algal cells (ACV), which is calculated as a biomass/number of cells ratio $[16,17]$. The average cenotic volume of the algal communities under study showed to be inversely correlated with water temperature (Fig. 6).

Correlation coefficients were the following:

- for phytoplankton $(r=-0.38, p<0.021, n=36)$;

- for epiphytic algae $(r=-0.64, p<0.001, n=23)$. 
The obtained findings show that when the water temperature elevates, the share of smallcelled algae in the "phytoplankton $\leftrightarrow$ epiphytic algal community" system increases. Our findings agree with the literature data [16], in accordance with which in summer season, when water temperature is high and herbivorous invertebrates' pressure is maximal, the competitive advantage is gained by species with larger relative surface area and high division rate.

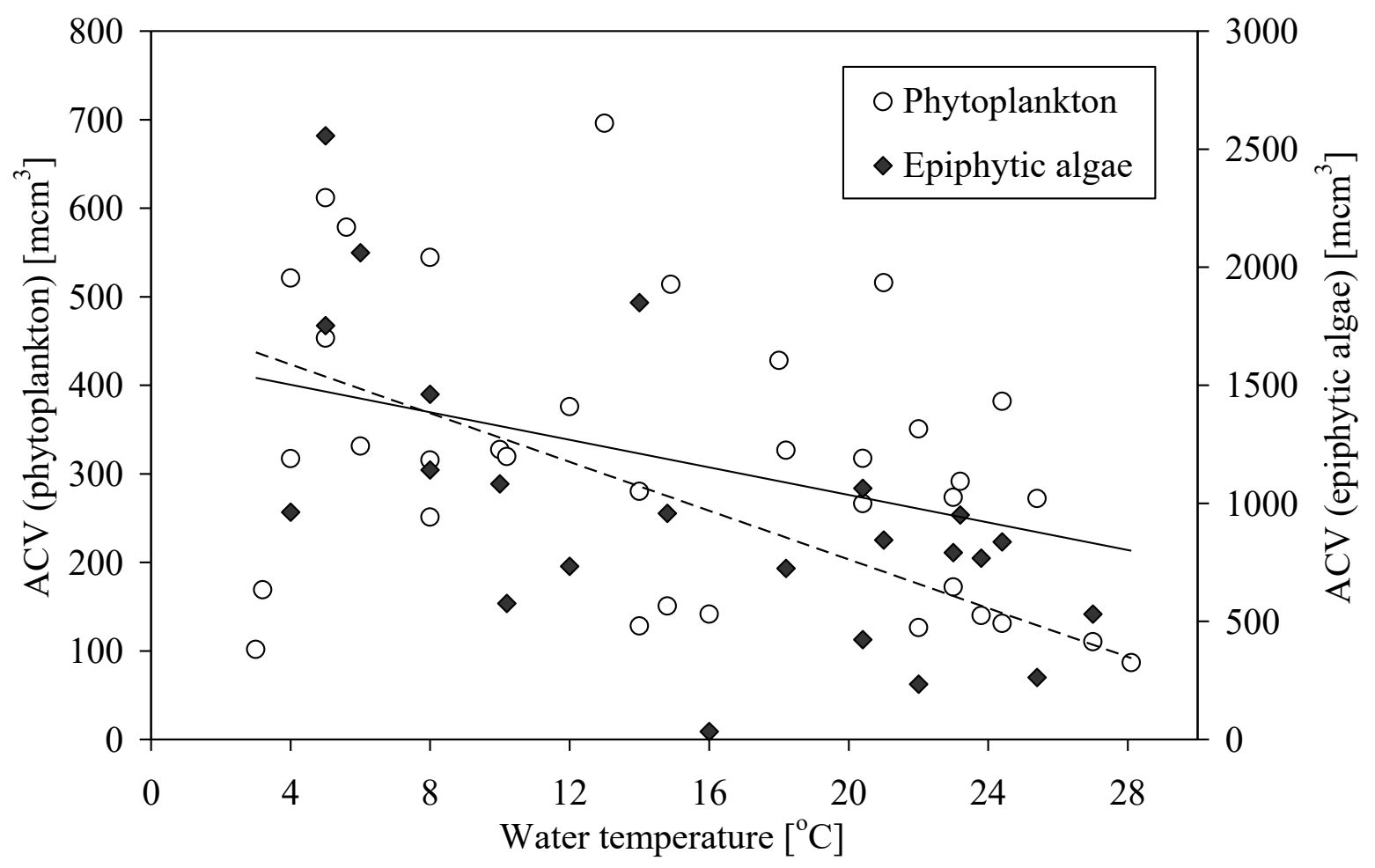

Figure 6. Correlation between the average cenotic volume of algal communities and water temperature.

\section{Conclusion}

It has been shown that phytoplankton and epiphytic algae are not isolated in space and time, but exist under mutual influence, forming the dynamic system "phytoplankton $\leftrightarrow$ epiphytic algal community". Several species were simultaneously present in both communities, and this was caused by: their habitat versatility, algae sedimentation from plankton to higher aquatic plants' surface and transition of typically epiphytic species to plankton owing to hydrodynamic processes.

The "phase opposition" was observed between phytoplankton and epiphytic algal communities: the maximal biomass of phytoplankton was recorded in summer, while that of epiphytic algae - in autumn. Such "phase opposition" is explained by different temperature optimums of dominant species and divisions in these communities, and also by shading of epiphytic algae by phytoplankton in case of intensive growth of the latter.

The revealed differences in development of phytoplankton and epiphytic algal communities indicate that certain mechanisms exist, which support the stability of the aquatic ecosystem functioning and during the year are determined by different autotrophic communities.

\section{Acknowledgment}

The authors express gratitude to junior researcher of the Institute of Hydrobiology of the NAS of Ukraine Mariia Ivanivna Linchuk for providing the data on permanganate and dichromate oxidation for the period under study. 


\section{References}

[1] L. Hansson, Factors regulating periphytic algal biomass, Limnology and Oceanography. 37(2) (1992) 322-328.

[2] T.A. Makarevich, Contribution of periphyton to total primary production of freshwater ecosystems (review), Bulletin of Tumen State University. 5 (2005) 77-86. (in Russian)

[3] A.A. Protasov, Conceptual models of the contourization processes in the aquatic ecosystems, Hydrobiological Journal. 50(1) (2014) 3-19.

[4] M. Scheffer, E.N. van Ness, Shallow lakes theory revised: various alternative regimes driven by climate, nutrients, depth and lake size, Hydrobiologia. 584(1) (2007) 455-466.

[5] Y. Vadeboncoeur, A.D. Steinman, Periphyton functions in lake ecosystems, The Scientific World. 2 (2002) 1449-1468.

[6] V.G. Deviatkin, Ye.V. Karpova, N.Yu. Meteleva, Development and productivity of periphyton in the Rybinsk water reservoir, in: Hydrobotany 2000, Proceedings of the $5^{\text {th }}$ AllRussian Conference on Aquatic Plants (Oct. 10-13 ${ }^{\text {th }}, 2000$ ), Borok, 2000, pp. 21-22. (in Russian)

[7] N.Yu. Meteleva, Structure and productivity of phytoperiphyton of the water bodies of the upper Volga Basin: Author's Abstract, Borok, Russia, 2013. (in Russian)

[8] A.I. Denisova et al., Hydrology and hydrochemistry of the Dnieper River and its water reservoirs, Naukova Dumka, Kyiv, Ukrainian SSR, 1989. (in Russian)

[9] Climate of Kyiv, ed. by. V.I. Osadchyi, O.O. Kosovets, V.M. Babinchenko, Nika-Center, Kyiv, Ukraine, 2010. (in Ukrainian)

[10] O.M. Arsan, O.A. Davydov, T.M. Diachenko, Methods of hydroecological studies of surface waters, ed. by V.D. Romanenko, Kyiv, Ukraine, 2006. (in Ukrainian)

[11] AlgaeBase. Available: http://www.algaebase.org.

[12] Diatom analysis. Book 1, ed. by A.N. Krishtofovich, State Publishing House of Geological Literature, Leningrad, USSR, 1949. (in Russian)

[13] O.V. Topachevksyi, O.P. Oksiiuk, Diatom algae - Bacillariophyta (Diatomeae), Publishing House of the Academy of Sciences of the Ukrainian SSR, Kyiv, 1960. (in Ukrainian)

[14] Yu.V. Bryantseva, A.M. Lyah, A.V. Sergeyeva, Calculation of volumes and surface areas of unicellular algae of the Black Sea, Sevastopol, Ukraine, 2005. (in Russian)

[15] L.G. Senichkina, Volumetric characteristics of oval and conic forms of planktonic algae cells, Hydrobiological Journal. 31(2) (1995) 103-108. (in Russian)

[16] V.G. Deviatkin, Dynamics of algal flora development in the Rybinsk water reservoir, in: Flora and Vegetation of Water Bodies of the Upper Volga Basin, Rybinsk, USSR, 1979, pp. 78108. (in Russian)

[17] V.G. Deviatkin, Development and productivity of littoral algal cenoses, Biology of Inland Waters. 51 (1981) 11-15. (in Russian)

[18] T. Sörensen, A method of establishing groups of equal amplitude in plant sociology based on similarity of species content, Kongelige Danske videns, Selskab. Biol. Krifter. 5(4) (1948) 148.

[19] H.G. Washington, Diversity, biotic and similarity indices. A review with special relevance to aquatic ecosystems, Water. Res. 18(6) (1984) 653-694. 
[20] B.Y. Nabyvanets et al., Analytical chemistry of surface waters, Naukova Dumka, Kyiv, Ukraine, 2007. (in Ukrainian)

[21] Central Geophysical Observatory, Kyiv, Official Website. Available: www.cgo.kiev.ua.

[22] V.I. Shcherbak et al., Seasonal and interannual dynamics of phytoplankton, phytomicroepiphyton, and nutrients content in the river section of the Kanev Reservoir, Hydrobiological Journal. 52(1) (2016) 49-61.

[23] O.P. Oksiyuk et al., Bottom vegetation of the river section of the Kanev Reservoir, Institute of Hydrobiology of the NAS of Ukraine, Kyiv, Ukraine, 2005. (in Russian)

[24] V.B. Lukin, Transformations in phytoperiphyton community in course of seasonal succession: sedimentation of planktonic forms and pressure of herbivores (chironomids larvae), J. General Biology. 63(5) (2002) 418-425. (in Russian)

[25] V.B. Lukin, Mechanisms forming periphyton species structure in course of seasonal succession: role of intespecies competition and sedimentation of planktonic forms, J. General Biology. 64(3) (2003) 263-272. (in Russian)

[26] V.I. Shcherbak, A.M. Zadorozhnaya, Seasonal dynamics of phytoplankton of the Kiev section of the Kanev Reservoir, Hydrobiological Journal. 49(4) (2013) 26-36.

[27] B. Fott, Algenkunde, Fischer, Stuttgart, 1971. 